Pak. j. sci. ind. res. Ser. A: phys. sci. 201255 (3) 155-162

\title{
Removal of Pollutants from the Liming Effluent in Course of Leather Processing
}

\author{
Niaz Ahmed ${ }^{a *}$, Muhammad Saeed Khana, Tahira Ayaz and Mouzam Ali Khanb \\ ${ }^{a}$ PCSIR-Leather Research Centre, D-102, SITE, South Avenue, Karachi, Pakistan \\ ${ }^{\mathrm{b}}$ Institute of Environmental Studies, University of Karachi, Karachi-75270, Pakistan
}

(received February 28, 2011; revised March 28, 2012; accepted May 3, 2012)

\begin{abstract}
In present work, the liming floats were treated with phosphoric acid, oxalic acid, acetic acid, boric acid and formic acid in different experiments to precipitate the suspended solids and then passed through the column filled with activated charcoal prepared from raw trimmings of cattle hides. The flow rate of $100 \mathrm{~mL} / \mathrm{min}$ was observed during the experiment. Considerable reductions of pollutants i.e. $88.84-99.56 \%$ of BOD, $78.87-99.6 \%$ of COD, $78.8-99.72 \%$ of suspended solids and $82.3-98.55 \%$ of total solids were removed in the treated liming float. Activated charcoal prepared from raw trimmings of cattle hides, a solids waste from leather industry was found an effective adsorbent to remove the pollutants from the liming floats.
\end{abstract}

Keywords: cattle hides, liming floats, pollutants, suspended solids, leather processing

\section{Introduction}

Leather is produced by transformation of raw hides or skins, a natural renewable resource, and is considered a valuable by-product of food industry. The hides and skins are processed by various steps of beamhouse, tanning and dyeing. The environmental impact of tanning industry is generally significant both in liquid and solid form for generation of wastes, i.e. high concentration of organic materials, salts and heavy metals (chromium compounds), raw trimmings of cattle hides, goat and sheep skins, and tanned trimmings. In order to bring the tanning industry more in line with present environmental safety, various methods have been devised to reduce the impact of leather manufacturing on the environment.

Protection of environment is a major concern all over the world. In the leather industry the overall effluent of a tannery can be segregated into a minor stream with less contamination and two main streams; the unhairing and the chrome tanning effluents, which have to be treated separately.

During various stages of leather processing the waste generated after liming execute the highest pollution load in terms of high BOD, COD, SS and TS than rest of the leather processing steps.

As a consequence, the liming effluent is characterized by high alkalinity containing sulphide, lime, surfactants,

*Author for correspondence; E-mail: niazmemon2000@yahoo.com destroyed hairs and the organic materials, the increased amount of COD, BOD, TS and TSS.

A number of technologies have been developed over the years to remove organic matter (expressed as chemical oxygen demand) from industrial waste water, the most important technologies include coagulation /flocculation process (Peres et al., 2004), membrane filtration (Galambo et al., 2004), oxidation process (Martinez et al., 2003), low cost and non conventional absorbents include treatment of waste water with modified cellulosic materials (Gupta et al., 2009; 2007; Okieimen et al., 1985), agricultural by-products (Moodley et al., 2011; Gupta et al., 2006a; Ahmedna et al., 1997), nutshells (Toles et al., 1998), using bagasse fly ash (Gupta and Sharma, 2003), wood, bone, pecan shell processed (Bansode et al., 2004) and into activated carbons (Tam and Antal, 1999).

Nomanbhay and Palanisamy (2005) have reported palm shell charcoal as an important absorbents for the removal of metals and organics from municipal and industrial waste water. Gupta et al. (2006b) have reported method for removal and recovery of the hazardous azo dye acid orange 7 through adsorption over waste materials. Advances in water treatment by adsorption technology has been reported by Ali and Gupta (2007).

The raw trimmings of cattle hides is a by-product of tannery which are obtained as a result of cutting extra proteinous material found at the edges of the skins and hides which are not used for leather manufacturing. 
They increase atmospheric pollution if not properly used such as converted into glue or gelatin.

Gupta and Rastogi (2009) have worked on biosorption of hexavalent chromium by raw and acid-treated green alga Oedogonium hatei from aqueous solutions. Biosorption of lead (II) from aqueous solutions by nonliving algal biomass Oedogonium sp. and Nostoc sp. has also been reported (Gupta and Rastogi, 2008a), by green algae Spirogyra species (Gupta and Rastogi, 2008 b) and biosorption by non-living algal biomass Oedogonium sp. (Gupta and Rastogi, 2008c).

Gupta and Ali (2001) have reported removal of DDD and DDE from wastewater using bagasse fly ash, and removal of endosulfan and methoxychlor from Water on carbon slurry (Gupta and Ali, 2008). Removal of lead from wastewater using bagasse fly ash has been studied by Gupta et al. (1998).

Charcoal was prepared from the raw trimmings of cattle hides which has been found an effective absorbent to reduce the pollution potential from the liming float on one hand provided the SS are removed or settled down from the liming float before treating with the charcoal, and reduced the obnoxious atmosphere caused by degradation of the raw trimmings on the other hand.

The main goal of the study is to utilize the raw trimming of cattle hides, a solid waste into an effective adsorbent for treatment of liming floats after removing SS from these floats so that the effectiveness of the charcoal remains at an optimum level and could not interfere the flow rate of the effluent to be treated.

\section{Materials and Methods}

Muffle furnace (Ogawa Seiki), Tokyo, Japan was used for carbonization in the preparation of charcoal. For analytical purpose chemicals of A.R grade were used. The double distilled water was used throughout the analytical work. All the glassware used for analytical purpose were of "A" type Pyrex. A glass tube column having length 1.5 ' feet and dia 4 " was used during the experimental work.

Phosphoric acid, oxalic acid, acetic acid, boric acid, and formic acid used to attain $\mathrm{pH}$ between 6.2-6.5 of liming effluent in different experiments were of technical grade.

For the determination of BOD, COD, Total suspended solids (TSS) and Total solids (TS) APHA 5210-B,
APHA 5220-C and APHA 2540 Solids-D (APHA, 1998) were used, respectively. Each parameter was validated by duplicate etermination. The liming floats for the treatment with the adsorbent prepared at laboratory scale were taken from goat skins (collected from Tannery A and Tannery B), sheep skins and cow hides leather production units.

Procedure for the preparation of the natural adsorbent. For the preparation of adsorbent the cattle hides trimmings were collected from a tannery. They were washed with tap water, drained and dried at room temperature, cut into small pieces and carbonized in a china dish in the muffle furnace. The temperature was raised gradually to $550{ }^{\circ} \mathrm{C}$ and the furnace was left for two hours to complete carbonization. Cattle hide trimmings $(1000 \mathrm{~g})$ were carbonized at one time.

The sample was allowed to cool, and the charcoal was ground and passed through a sieve of mesh size $80.5 \mathrm{~cm}^{3} .1 \mathrm{M} \mathrm{HCl}$ was used to activate each $500 \mathrm{~g}$ of charcoal, washed with water at $70{ }^{\circ} \mathrm{C}$ until the filtrate was acid free.

For statistical validation all experiments and analysis were performed in duplicate. It has been mentioned in Tables 1-4.

Determination of biological oxygen demand (BOD). $\mathrm{BOD}$ is defined as the measure of the amount of oxygen used in respiration processes of microorganism in oxidizing organic matter in wastewater and for further metabolism of cellular components synthesized from the waste;

$$
\text { BOD mg/L }=\frac{\mathrm{D}_{1}-\mathrm{D}_{2}}{\mathrm{P}}
$$

where:

$\mathrm{D}_{1}=\mathrm{DO}$ of diluted sample immediately after preparation, $\mathrm{mg} / \mathrm{L}$

$\mathrm{D}_{2}=\mathrm{DO}$ of diluted sample after 5 days incubation at $20^{\circ} \mathrm{C}, \mathrm{mg} / \mathrm{L}$

$\mathrm{P}=$ decimal volumetric fraction of sample used.

The BOD concentration in liquid phase was determined at the beginning $\left(\mathrm{C}_{\mathrm{i}}\right)$ and after passing the column $\left(\mathrm{C}_{\mathrm{f}}\right)$ i.e. quantity of adsorbent in grams.

i. To compute the removal of BOD by the sorbent, the following equation was used;

$$
\% \text { Sorption }(\mathrm{BOD})=\frac{\left(\mathrm{C}_{\mathrm{i}}-\mathrm{C}_{\mathrm{f}}\right)}{\mathrm{C}_{\mathrm{i}}} \times 100
$$


where:

$$
\begin{aligned}
& \mathrm{C}_{\mathrm{i}}=\text { initial BOD concentration in } \mathrm{mg} / \mathrm{L} \\
& \mathrm{C}_{\mathrm{f}}=\text { final BOD concentration in } \mathrm{mg} / \mathrm{L}
\end{aligned}
$$

Determination of chemical oxygen demand (COD). The COD determination is a measure of the oxygen equivalent to that portion of the organic matter in the sample that is susceptible to oxidation by a strong oxidizing agent.

$$
\mathrm{COD} \mathrm{mg} / \mathrm{L}=\frac{(\mathrm{A}-\mathrm{B}) \mathrm{C} \times 8000}{\text { volume of sample }}
$$

where:

$$
\begin{aligned}
& \mathrm{A}=\mathrm{mL} \text { of } \mathrm{Fe}\left(\mathrm{NH}_{4}\right)_{2}\left(\mathrm{SO}_{4}\right) \text { for blank } \\
& \mathrm{B}=\mathrm{mL} \text { of } \mathrm{Fe}\left(\mathrm{NH}_{4}\right)_{2}\left(\mathrm{SO}_{4}\right) \text { for sample } \\
& \mathrm{C}=\text { normality of } \mathrm{Fe}\left(\mathrm{NH}_{4}\right)_{2}\left(\mathrm{SO}_{4}\right)
\end{aligned}
$$

The COD concentration in liquid phase was determined at the beginning $\left(\mathrm{C}_{\mathrm{i}}\right)$ and after passing the column $\left(\mathrm{C}_{\mathrm{f}}\right)$ ie. quantity of adsorbent in grams.

ii. The following equation was used to compute the removal of COD by the sorbent;

$$
\% \text { Sorption }(\mathrm{COD})=\frac{\left(\mathrm{C}_{\mathrm{i}}-\mathrm{C}_{\mathrm{f}}\right)}{\mathrm{C}_{\mathrm{i}}} \times 100
$$

where:

$\mathrm{C}_{\mathrm{i}}=$ initial COD concentration in $\mathrm{mg} / \mathrm{L}$

$\mathrm{C}_{\mathrm{f}}=$ final $\mathrm{COD}$ concentration in $\mathrm{mg} / \mathrm{L}$

Determination of total suspended solids (TSS). The total suspended solids were calculated as follows;

$\operatorname{mg~TSS} / \mathrm{L}=(\mathrm{A} \times \mathrm{B}) 1000 / \mathrm{mL}$ of sample

where:

$\mathrm{A}=$ weight of dried residue at $103-105{ }^{\circ} \mathrm{C}+\mathrm{dish}$ in

$\mathrm{mg}$

$\mathrm{B}=$ weight of dish in $\mathrm{mg}$

iii. The following equation was used to compute the removal of total suspended solids;

$\%$ Sorption $($ Total suspended solids $)=\frac{\left(\mathrm{C}_{\mathrm{i}}-\mathrm{C}_{\mathrm{f}}\right)}{\mathrm{C}_{\mathrm{i}}} \times 100$

where:

$\mathrm{C}_{\mathrm{i}}=$ initial total suspended solids concentration in $\mathrm{mg} / \mathrm{L}$

$\mathrm{C}_{\mathrm{f}}=$ final total suspended solids concentration in $\mathrm{mg} / \mathrm{L}$
Determination of total solids (TS). The total solids were calculated as follows;

$\mathrm{mg} \mathrm{TS} / \mathrm{L}=(\mathrm{A} \times \mathrm{B}) 1000 / \mathrm{mL}$ of sample

where:

$\mathrm{A}=$ weight of dried residue at $103-105^{\circ} \mathrm{C}+$ dish in $\mathrm{mg}$

$\mathrm{B}=$ weight of dish in $\mathrm{mg}$

iv. The following equation was used to compute the removal of total solids;

$\%$ Sorption $($ Total solids $)=\frac{\left(\mathrm{C}_{\mathrm{i}}-\mathrm{C}_{\mathrm{f}}\right)}{\mathrm{C}_{\mathrm{i}}} \times 100$

where:

$\mathrm{C}_{\mathrm{i}}=$ initial total solids concentration in $\mathrm{mg} / \mathrm{L}$

$\mathrm{C}_{\mathrm{f}}=$ final total solids concentration in $\mathrm{mg} / \mathrm{L}$

In different experiments one litre liming float was taken in a beaker, stirred and treated by weak acids namely; phosphoric acid, oxalic acid, acetic acid, boric acid and formic acid to achieve $\mathrm{pH}$ between 6.2-6.6 and then passed through the absorbent prepared from the raw trimmings of cattle hides keeping the quantity of absorbent constant i.e $500 \mathrm{~g}$ in each experiment.

\section{Results and Discussion}

The liming float generated in course of leather processing has the highest pollution load (Gehard, 1997). The effluent must be treated to an optimum level before discharging in public sewers. The liming float is characterized by high BOD, COD, TS, TSS and organic matters.

The suspended solids create problem in the treatment of tannery effluent unless they are settled down. They do not settle unless there are changes in $\mathrm{pH}$ or temperature of the effluents (Sarkar, 1981).

The flow rate is $50 \mathrm{~mL} / \mathrm{min}$ when TSS are not removed from the liming float and passed through the absorbent prepared from raw trimmings of goat skins (Ahmed and Khan, 2008). But the flow rate increased upto $100 \mathrm{~mL} / \mathrm{min}$ when the barrier of the $\mathrm{SS}$ in flow is removed.

The removal of pollutants from the liming float collected from different sources as a result of treating of liming floats with the activated charcoal prepared from the raw trimming of cattle hides after removal of SS from these floats are reported in the Tables 1-4. Table 5 represents the average removal of pollutants (Tables 1-4). 
Table 1. Mean values of removal of TS, TSS, COD and BOD from goat skin liming float collected from tannery A

\begin{tabular}{|c|c|c|c|c|c|c|c|c|c|c|c|}
\hline Parameters & $\begin{array}{l}\text { Fresh } \\
\text { (Mean } \\
\text { value) }\end{array}$ & $\begin{array}{l}\text { Phosphoric } \\
\text { acid } \\
(13 \mathrm{~mL})\end{array}$ & $\begin{array}{l}\text { Removal } \\
\%\end{array}$ & $\begin{array}{l}\text { Oxalic } \\
\text { acid } \\
(15 \mathrm{~g})\end{array}$ & $\begin{array}{l}\text { Removal } \\
\%\end{array}$ & $\begin{array}{l}\text { Acetic } \\
\text { acid } \\
(25 \mathrm{~mL})\end{array}$ & $\begin{array}{l}\text { Removal } \\
\%\end{array}$ & $\begin{array}{l}\text { Boric } \\
\text { acid } \\
(550 \mathrm{~g})\end{array}$ & $\begin{array}{l}\text { Removal } \\
\%\end{array}$ & $\begin{array}{l}\text { Formic } \\
\text { acid } \\
(13 \mathrm{~mL})\end{array}$ & $\begin{array}{l}\text { Removal } \\
\%\end{array}$ \\
\hline $\begin{array}{l}\text { Sludge } \\
(\mathrm{mL})\end{array}$ & - & $100 \mathrm{~mL}$ & - & $250 \mathrm{~mL}$ & - & $150 \mathrm{~mL}$ & - & $400 \mathrm{~mL}$ & - & $100 \mathrm{~mL}$ & - \\
\hline $\mathrm{pH}$ & 13.5 & 6.2 & - & 6.25 & - & 6.2 & - & 6.3 & - & 6.2 & - \\
\hline $\begin{array}{l}\mathrm{TS} \\
(\mathrm{mg} / \mathrm{L})\end{array}$ & 88188 & 1368 & 98.4 & 1628 & 98.1 & 1364 & 98.4 & 10472 & 88.1 & 1504 & 98.3 \\
\hline $\begin{array}{l}\text { TSS } \\
(\mathrm{mg} / \mathrm{L})\end{array}$ & 31876 & 112 & 99.6 & 104 & 99.6 & 92 & 99.7 & 3196 & 89.9 & 90 & 99.7 \\
\hline $\begin{array}{l}\mathrm{COD} \\
(\mathrm{mg} / \mathrm{L})\end{array}$ & 43199 & 474 & 98.9 & 474 & 98.9 & 474 & 98.9 & 1762 & 95.9 & 401 & 99.1 \\
\hline $\begin{array}{l}\text { BOD } \\
(\mathrm{mg} / \mathrm{L})\end{array}$ & 13712 & 140 & 98.9 & 122 & 99.1 & 140 & 98.9 & 863 & 93.7 & 71 & 99.5 \\
\hline
\end{tabular}

All analytical analysis was performed in duplicate.

Table 2. Mean values of removal of TS, TSS, COD and BOD from sheep skin liming float

\begin{tabular}{|c|c|c|c|c|c|c|c|c|c|c|c|}
\hline Parameters & $\begin{array}{l}\text { Fresh } \\
\text { (Mean } \\
\text { value) }\end{array}$ & $\begin{array}{l}\text { Phosphoric } \\
\text { acid } \\
(8 \mathrm{~mL})\end{array}$ & $\begin{array}{l}\text { Removal } \\
\%\end{array}$ & $\begin{array}{l}\text { Oxalic } \\
\text { acid } \\
(12 \mathrm{~g})\end{array}$ & $\begin{array}{l}\text { Removal } \\
\%\end{array}$ & $\begin{array}{l}\text { Acetic } \\
\text { acid } \\
(15 \mathrm{~mL})\end{array}$ & $\begin{array}{l}\text { Removal } \\
\%\end{array}$ & $\begin{array}{l}\text { Boric } \\
\text { acid } \\
(530 \mathrm{~g})\end{array}$ & $\begin{array}{l}\text { Removal } \\
\%\end{array}$ & $\begin{array}{l}\text { Formic } \\
\text { acid } \\
(11 \mathrm{~mL})\end{array}$ & $\begin{array}{l}\text { Removal } \\
\%\end{array}$ \\
\hline $\begin{array}{l}\text { Sludge } \\
(\mathrm{mL})\end{array}$ & - & $150 \mathrm{~mL}$ & - & $150 \mathrm{~mL}$ & - & $100 \mathrm{~mL}$ & - & $350 \mathrm{~mL}$ & - & $100 \mathrm{~mL}$ & - \\
\hline $\mathrm{pH}$ & 13.4 & 6.3 & - & 6.2 & - & 6.3 & - & 6.4 & - & 6.3 & - \\
\hline $\begin{array}{l}\text { TS } \\
(\mathrm{mg} / \mathrm{L})\end{array}$ & 61652 & 3756 & 93 & 1928 & 96.9 & 1998 & 96.7 & 9885 & 88.9 & 528 & 99.1 \\
\hline $\begin{array}{l}\text { TSS } \\
(\mathrm{mg} / \mathrm{L})\end{array}$ & 15344 & 180 & 98.8 & 700 & 95.4 & 180 & 98.8 & 3245 & 78.9 & 52 & 99.6 \\
\hline $\begin{array}{l}\mathrm{COD} \\
(\mathrm{mg} / \mathrm{L})\end{array}$ & 32695 & 1058 & 96.7 & 632 & 98.0 & 408 & 98.7 & 2231 & 93.2 & 401 & 98.8 \\
\hline $\begin{array}{l}\text { BOD } \\
(\mathrm{mg} / \mathrm{L})\end{array}$ & 11299 & 49 & 99.5 & 150 & 98.7 & 160 & 98.6 & 1098 & 90.3 & 71 & 99.3 \\
\hline
\end{tabular}

All analytical analysis was performed in duplicate.

Table 3. Mean values of removal of TS, TSS, COD and BOD from goat skin liming float collected from Tannery B

\begin{tabular}{|c|c|c|c|c|c|c|c|c|c|c|c|}
\hline Parameters & $\begin{array}{l}\text { Fresh } \\
\text { (Mean } \\
\text { value) }\end{array}$ & $\begin{array}{l}\text { Phosphoric } \\
\text { acid } \\
(15 \mathrm{~mL})\end{array}$ & $\begin{array}{l}\text { Removal } \\
\%\end{array}$ & $\begin{array}{l}\text { Oxalic } \\
\text { acid } \\
(15 \mathrm{~g})\end{array}$ & $\begin{array}{l}\text { Removal } \\
\%\end{array}$ & $\begin{array}{l}\text { Acetic } \\
\text { acid } \\
(25 \mathrm{~mL})\end{array}$ & $\begin{array}{l}\text { Removal } \\
\%\end{array}$ & $\begin{array}{l}\text { Boric } \\
\text { acid } \\
(350 \mathrm{~g})\end{array}$ & $\begin{array}{l}\text { Removal } \\
\%\end{array}$ & $\begin{array}{l}\text { Formic } \\
\text { acid } \\
(13 \mathrm{~mL})\end{array}$ & $\begin{array}{l}\text { Removal } \\
\%\end{array}$ \\
\hline $\begin{array}{l}\text { Sludge } \\
(\mathrm{mL})\end{array}$ & - & $100 \mathrm{~mL}$ & - & $250 \mathrm{~mL}$ & - & $150 \mathrm{~mL}$ & - & $400 \mathrm{~mL}$ & - & $100 \mathrm{~mL}$ & - \\
\hline $\mathrm{pH}$ & 13.0 & 6.1 & - & 6.2 & - & 6.2 & - & 6.4 & - & 6.3 & - \\
\hline $\begin{array}{l}\mathrm{TS} \\
(\mathrm{mg} / \mathrm{L})\end{array}$ & 59180 & 1368 & 97.7 & 2030 & 96.6 & 1850 & 96.9 & 10472 & 82.3 & 1830 & 96.9 \\
\hline $\begin{array}{l}\text { TSS } \\
(\mathrm{mg} / \mathrm{L})\end{array}$ & 15128 & 112 & 99.2 & 734 & 95.1 & 718 & 95.2 & 3196 & 78.9 & 680 & 95.5 \\
\hline $\begin{array}{l}\text { COD } \\
(\mathrm{mg} / \mathrm{L})\end{array}$ & 12808 & 533 & 95.8 & 750 & 94.1 & 596 & 95.3 & 1763 & 86.2 & 560 & 95.6 \\
\hline $\begin{array}{l}\text { BOD } \\
(\mathrm{mg} / \mathrm{L})\end{array}$ & 7736 & 169 & 97.8 & 176 & 97.7 & 140 & 98.2 & 863 & 88.8 & 150 & 98.0 \\
\hline
\end{tabular}

\footnotetext{
All analytical analysis was performed in duplicate.
} 
This average removal is also shown statistically through Figs. 1-3.

It is clear from the Tables 1, 2, 3 and 4 that the quantities of acids namely; phosphoric acid, oxalic acid, acetic acid and formic acid used per litre of liming effluent to settle the SS are $13 \mathrm{~mL}, 8 \mathrm{~mL}, 15 \mathrm{~mL} \& 15 \mathrm{~mL}, 15 \mathrm{~g}$, $12 \mathrm{~g}, 15 \mathrm{~g} \& 20 \mathrm{~g}, 25 \mathrm{~mL}, 15 \mathrm{~mL}, 25 \mathrm{~mL}$, \& $27 \mathrm{~mL}$, $13 \mathrm{~mL}, 11 \mathrm{~mL}, 13 \mathrm{~mL}, \& 14.9 \mathrm{~mL}$, respectively, which is quite negligible quantity with the exception of boric acid which is $550 \mathrm{~g}, 530 \mathrm{~g}, 350 \mathrm{~g}$ and $550 \mathrm{~g}$ accordingly and obviously higher than the preceding acids.

It is well known that boric acid, acetic acid and phosphoric acid are eco friendly. Formic acid is frequently used in the leather manufacturing such as pickling and fixing of acid dyestuffs. These weak acids were used to lower the $\mathrm{pH}$ of the liming float to attain $\mathrm{pH}$ between 6.2-6.5 so that the SS can be settled down which have negative impact on flow rate when the effluent is passed through adsorbent.

The strong acids like sulphuric acid and hydrochloric acid were avoided to settle the SS as these have stringent environmental affect.

Table 1 shows that, the sludge obtained is lowest in the effluents treated with phosphoric acid and formic acid and highest in case of boric acid.

The removal of total solids from the treated effluent with phosphoric acid and acetic acid were highest and the lowest removal was with boric acid.

Table 4. Mean values of removal of TS, TSS, COD and BOD from liming float (cow hides processing)

\begin{tabular}{|c|c|c|c|c|c|c|c|c|c|c|c|}
\hline Parameters & $\begin{array}{l}\text { Fresh } \\
\text { (Mean } \\
\text { value) }\end{array}$ & $\begin{array}{l}\text { Phosphoric } \\
\text { acid } \\
(15.5 \mathrm{~mL})\end{array}$ & $\begin{array}{l}\text { Removal } \\
\%\end{array}$ & $\begin{array}{l}\text { Oxalic } \\
\text { acid } \\
(20 \mathrm{~g})\end{array}$ & $\begin{array}{l}\text { Removal } \\
\%\end{array}$ & $\begin{array}{l}\text { Acetic } \\
\text { acid } \\
(27 \mathrm{~mL})\end{array}$ & $\begin{array}{l}\text { Removal } \\
\%\end{array}$ & $\begin{array}{l}\text { Boric } \\
\text { acid } \\
(550 \mathrm{~g})\end{array}$ & $\begin{array}{l}\text { Removal } \\
\%\end{array}$ & $\begin{array}{l}\text { Formic } \\
\text { acid } \\
(14.9 \mathrm{~mL})\end{array}$ & $\begin{array}{l}\text { Removal } \\
\%\end{array}$ \\
\hline $\begin{array}{l}\text { Sludge } \\
(\mathrm{mL})\end{array}$ & - & $110 \mathrm{~mL}$ & - & $270 \mathrm{~mL}$ & - & $160 \mathrm{~mL}$ & - & $430 \mathrm{~mL}$ & - & $110 \mathrm{~mL}$ & - \\
\hline $\mathrm{pH}$ & 13.2 & 6.3 & - & 6.3 & - & 6.2 & - & 6.3 & - & 6.2 & - \\
\hline $\begin{array}{l}\mathrm{TS} \\
(\mathrm{mg} / \mathrm{L})\end{array}$ & 90112 & 1298 & 98.5 & 1414 & 98.4 & 1445 & 98.4 & 11075 & 87.7 & 1498 & 98.33 \\
\hline $\begin{array}{l}\text { TSS } \\
(\mathrm{mg} / \mathrm{L})\end{array}$ & 34662 & 113 & 99.7 & 113 & 99.7 & 95 & 99.7 & 3729 & 89.2 & 122 & 99.6 \\
\hline $\begin{array}{l}\text { COD } \\
(\mathrm{mg} / \mathrm{L})\end{array}$ & 36346 & 480 & 98.8 & 501 & 98.6 & 532 & 98.5 & 1598 & 95.6 & 465 & 98.71 \\
\hline $\begin{array}{l}\text { BOD } \\
(\mathrm{mg} / \mathrm{L})\end{array}$ & 14015 & 152 & 98.9 & 231 & 98.3 & 180 & 98.7 & 802 & 94.3 & 176 & 98.74 \\
\hline
\end{tabular}

(All analytical analysis were performed in duplicate)

Table 5. Removal of TS, TSS, COD and BOD from liming float (Average of Tables 1-4 with SD)

\begin{tabular}{|c|c|c|c|c|c|c|c|c|c|c|c|}
\hline Parameters & Fresh & $\begin{array}{l}\text { Phosphoric } \\
\text { acid } \\
(12.9 \mathrm{~mL}) \\
\text { used }\end{array}$ & $\begin{array}{l}\text { Removal } \\
\%\end{array}$ & $\begin{array}{l}\text { Oxalic } \\
\text { acid } \\
(15.5 \mathrm{~g}) \\
\text { used }\end{array}$ & $\begin{array}{l}\text { Removal } \\
\%\end{array}$ & $\begin{array}{l}\text { Acetic } \\
\text { acid } \\
(23 \mathrm{~mL}) \\
\text { used }\end{array}$ & $\begin{array}{l}\text { Removal } \\
\%\end{array}$ & $\begin{array}{l}\text { Boric } \\
\text { acid } \\
(495 \mathrm{~g}) \\
\text { used }\end{array}$ & $\begin{array}{l}\text { Removal } \\
\%\end{array}$ & $\begin{array}{l}\text { Formic } \\
\text { acid } \\
(12.975 \mathrm{~mL}) \\
\text { used }\end{array}$ & $\begin{array}{l}\text { Removal } \\
\%\end{array}$ \\
\hline $\begin{array}{l}\text { Sludge } \\
\mathrm{mL}\end{array}$ & & $\begin{array}{l}115 \\
\pm 23.8\end{array}$ & & $\begin{array}{l}230 \\
\pm 54\end{array}$ & & $\begin{array}{l}140 \\
\pm 27\end{array}$ & & $\begin{array}{l}395 \\
\pm 33.1\end{array}$ & & $\begin{array}{l}102 \\
\pm 5.2\end{array}$ & \\
\hline $\mathrm{pH}$ & $\begin{array}{l}13.28 \\
\pm 0.23\end{array}$ & $\begin{array}{l}6.2 \\
\pm 0.07\end{array}$ & & $\begin{array}{l}6.26 \\
\pm 0.06\end{array}$ & & $\begin{array}{l}6.23 \\
\pm 0.03\end{array}$ & & $\begin{array}{l}6.35 \\
\pm 0.05\end{array}$ & & $\begin{array}{l}6.28 \\
\pm 0.6\end{array}$ & \\
\hline $\begin{array}{l}\mathrm{TS} \\
\mathrm{mg} / \mathrm{L}\end{array}$ & $\begin{array}{l}74783 \\
\pm 16638\end{array}$ & $\begin{array}{l}1947 \\
\pm 1206\end{array}$ & $\begin{array}{l}96.9 \\
\pm 2.6 \\
74783\end{array}$ & $\begin{array}{l}1750 \\
\pm 281\end{array}$ & $\begin{array}{l}97.5 \\
\pm 0.9 \\
24252.5\end{array}$ & $\begin{array}{l}1664 \\
\pm 307\end{array}$ & $\begin{array}{l}97.6 \\
\pm 0.9 \\
31262.28\end{array}$ & $\begin{array}{l}10476 \\
\pm 485\end{array}$ & $\begin{array}{l}86.3 \\
\pm 4.7 \\
11690.75\end{array}$ & $\begin{array}{l}1340 \\
\pm 563\end{array}$ & $\begin{array}{l}98.2 \\
\pm 0.3\end{array}$ \\
\hline $\begin{array}{l}\mathrm{TSS} \\
\mathrm{mg} / \mathrm{L}\end{array}$ & $\begin{array}{l}24252 \\
\pm 9605\end{array}$ & $\begin{array}{l}129 \\
\pm 33\end{array}$ & $\begin{array}{l}99.3 \\
\pm 0.4\end{array}$ & $\begin{array}{l}413 \\
\pm 351\end{array}$ & $\begin{array}{l}97.4 \\
\pm 2.5\end{array}$ & $\begin{array}{l}271 \\
\pm 300\end{array}$ & $\begin{array}{l}98.4 \\
\pm 2\end{array}$ & $\begin{array}{l}3341 \\
\pm 1763\end{array}$ & $\begin{array}{l}84.2 \\
\pm 6.2\end{array}$ & $\begin{array}{l}236 \\
\pm 297\end{array}$ & $\begin{array}{l}98.6 \\
\pm 2\end{array}$ \\
\hline $\begin{array}{l}\text { COD } \\
\mathrm{mg} / \mathrm{L}\end{array}$ & $\begin{array}{l}31262 \\
\pm 1305\end{array}$ & $\begin{array}{l}636 \\
\pm 282\end{array}$ & $\begin{array}{l}97.5 \\
\pm 1.5\end{array}$ & $\begin{array}{l}589 \\
\pm 127\end{array}$ & $\begin{array}{l}97.4 \\
\pm 2.2\end{array}$ & $\begin{array}{l}502 \\
\pm 80\end{array}$ & $\begin{array}{l}97.8 \\
\pm 1.7\end{array}$ & $\begin{array}{l}1839 \\
\pm 273\end{array}$ & $\begin{array}{l}92.7 \\
\pm 4.5\end{array}$ & $\begin{array}{l}457 \\
\pm 75\end{array}$ & $\begin{array}{l}98.0 \\
\pm 1.6\end{array}$ \\
\hline $\begin{array}{l}\text { BOD } \\
\mathrm{mg} / \mathrm{L}\end{array}$ & $\begin{array}{l}11691 \\
\pm 1794\end{array}$ & $\begin{array}{l}127 \\
\pm 53\end{array}$ & $\begin{array}{l}98.8 \\
\pm 0.7\end{array}$ & $\begin{array}{l}170 \\
\pm 46\end{array}$ & $\begin{array}{l}98.4 \\
\pm 0.6\end{array}$ & $\begin{array}{l}155 \\
\pm 19\end{array}$ & $\begin{array}{l}98.6 \\
\pm 0.3\end{array}$ & $\begin{array}{l}906 \\
\pm 131\end{array}$ & $\begin{array}{l}91.7 \\
\pm 2.6\end{array}$ & $\begin{array}{l}117 \\
\pm 54\end{array}$ & $\begin{array}{l}98.9 \\
\pm 0.7\end{array}$ \\
\hline
\end{tabular}

Average tables 1-4. 


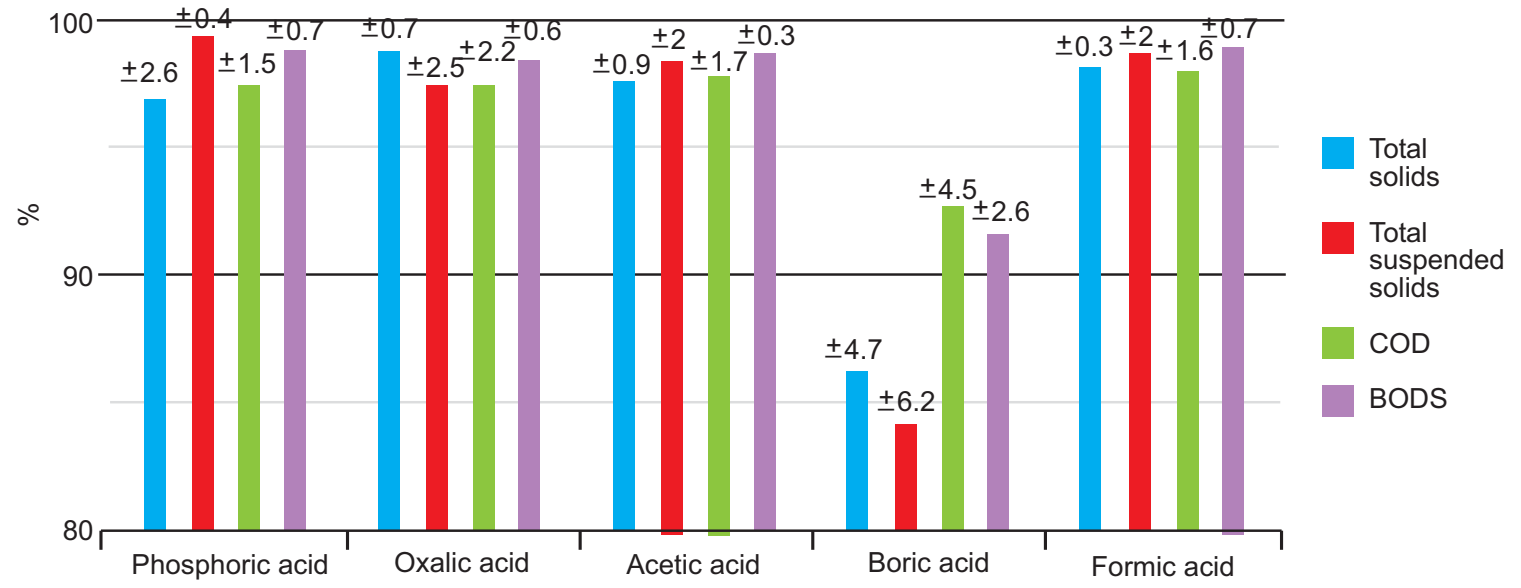

Fig. 1. Removal of Pollutants (average Table 1-4 with SD).

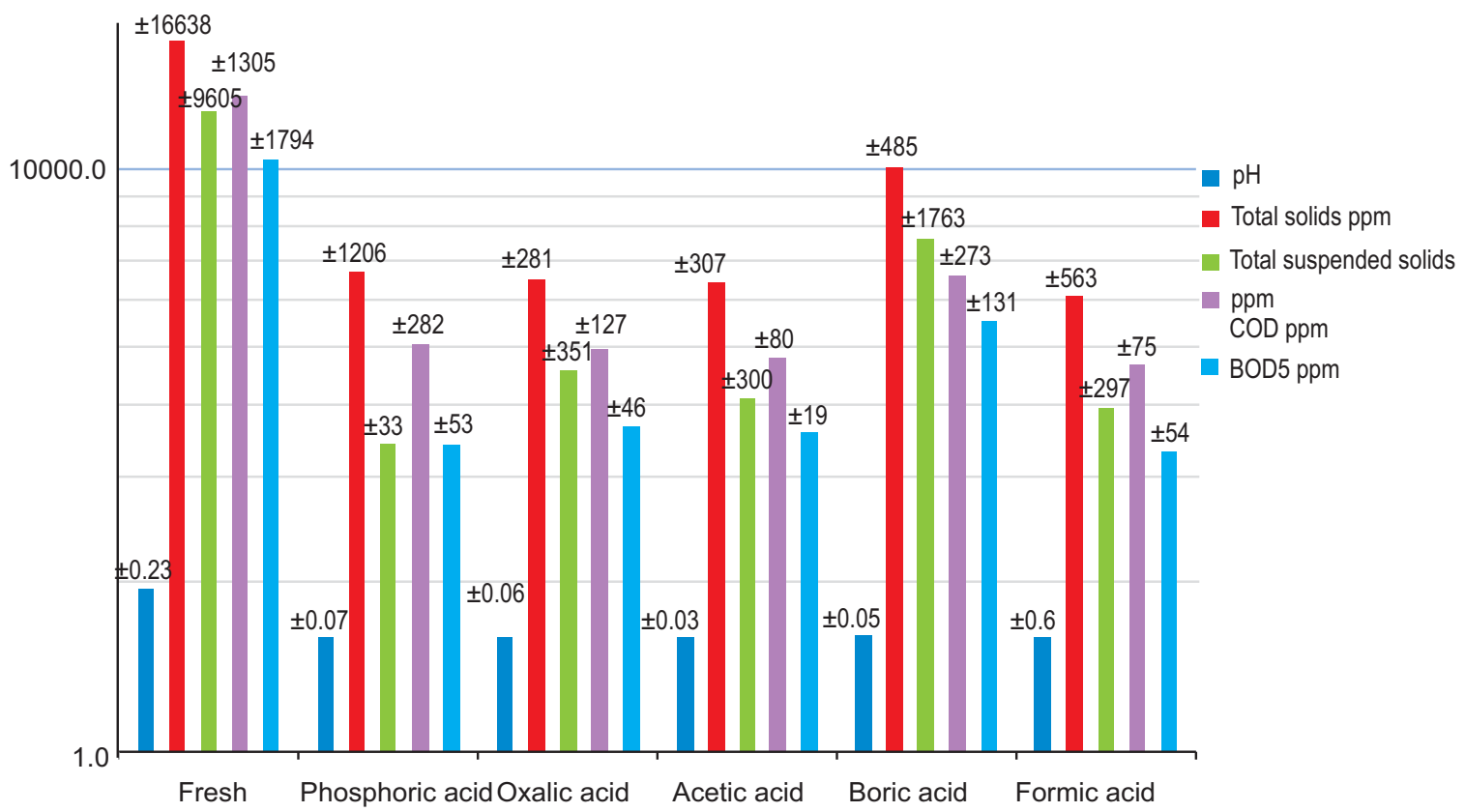

Fig. 2. Comparison of fresh sample of liming float with treated samples of weak acids.

The removal of TSS from the effluent was highest in case of acetic acid and the lowest in case of boric acid. The removals of COD and BOD were highest in case of formic acid and the lowest in case of boric acid.

The results shown in Table 2 indicate that, the sludge obtained is highest in case of boric acid and the lowest in case of phosphoric acid. The removal of TS was highest in case of acetic acid and lowest in case of boric acid.

The removal of TSS, COD and BOD were highest in case of phosphoric acid and lowest in case of boric acid.
Table 3 indicates the sludge obtained is the lowest in the effluent treated with phosphoric acid and formic acid and higher in case of boric acid. The removal of SS from the effluent was the highest in case of phosphoric acid. The removal of TS from the effluent treated with phosphoric acid was highest and the lowest removal was with boric acid. The removal of COD was the highest in case of phosphoric acid and lowest in case of boric acid. The removal of BOD was the highest in case of acetic acid and lowest in case of boric acid.

It is clear from Table 4, that the sludge obtained is the lowest in the effluent treated with phosphoric acid and 


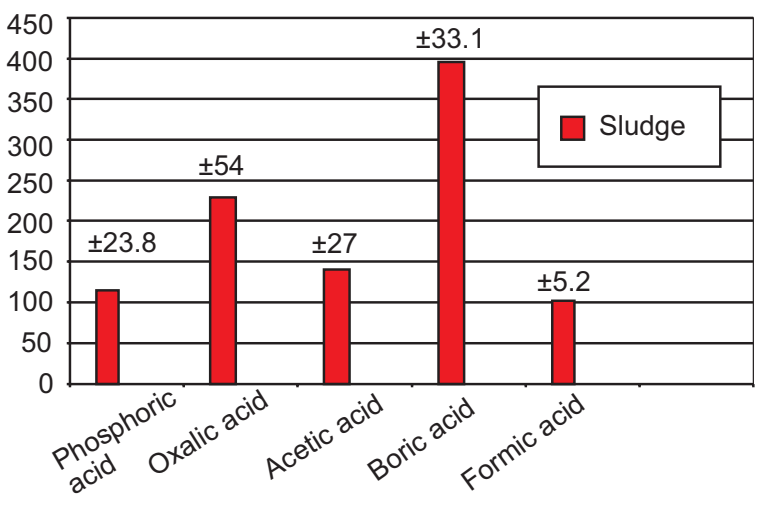

Fig. 3. Average table 1-4 (sludge formation in $\mathrm{mL}$ with SD).

formic acid. The removal of TS, COD and BOD were the highest from the effluent treated with phosphoric acid and lowest with boric acid. The removal of TSS from the effluent treated with acetic acid was highest and lowest in case of boric acid.

\section{Conclusion}

The absorbent prepared from the raw trimmings of cattle hides is an effective absorbent for the reduction of BOD, COD and TS from the liming float. The flow rate of the liming float by treatment with the absorbent can be considerably increased i.e. $100 \mathrm{~mL}$ per minute provided the TSS are removed from the effluent by treating with weak acids namely; phosphoric acid, oxalic acid, acetic acid, boric acid and formic acid. It was observed that the boric acid is less effective to remove TSS as compared to preceding acids. It was also concluded that higher amount of boric acid is required to remove TSS as compared to the preceding acids.

The cattle trimmings are solid waste and create serious problem of health hazards if not properly disposed or utilized for glue making.

Utilization of cattle trimmings for the production of an absorbent will remove the pollution load caused by the raw trimmings.

Reduction of 88.84-99.56\% of BOD, 78.87-99.6\% of COD, $78.8-99.72 \%$ of TSS and $82.3-98.55 \%$ of TS can be achieved by treatment of the liming float with the charcoal prepared from the raw trimmings if the liming float is pre treated with weak acids to settle down the suspended solids.
The work was carried out at laboratory scale and may be extended to large scale.

\section{References}

Ahmedna, M., Johns, M.M., Clarke, S.J., Marshall, W.E., Rao, R.M. 1997. Potential of agricultural by product based activated carbons for use in raw sugar decolourization. Journal of the Science of Food and Agriculture, 75: 117-124.

Ahmed, N., Khan, M.S. 2008. Waste removal with animal skin charcoal. Leather International, 210: 28-29.

Ali, I., Gupta, V.K. 2007. Advances in water treatment by adsorption technology. Nature Protocols, 1: 2661-2667.

APHA. 1998. Standard Methods for the Examination of Water and Waste Water, $20^{\text {th }}$ edition, 1998, American Public Health Association, USA.

Bansode, R.R., Losso, J.N., Marshall, W.E., Rao, R.M., Portier, R.J. 2004. Pecan shell - based granular activated carbon for treatment of chemical oxygen demand (COD) in municipal wastewater. Bioresource Technology, 94: 129-135.

Galambos, I.I., Molina, J.M., Jaray, P., Vatai, G., BekassyMolnar, E. 2004. High organic content industrial wastewater treatment by membrane filtration. Desalination, 162: 117-120.

Gehard, J. 1997. Possible Defects in Leather Production, 275 pp., Druck Partner Rubelmann GMBH, Carl Benz-Strasse 11, D-69495, Hemsbach, Germany.

Gupta, V.K., Carrott, P.J.M., Ribeiro, M.M.L. 2009. Low-cost adsorbents: Growing approach to wastewater treatment - a review. Critical Reviews in Environmental Science and Technology, 39: 783-842.

Gupta, V.K., Rastogi, A. 2009. Biosorption of hexavalent chromium by raw and acid-treated green alga Oedogonium hatei from aqueous solutions. Journal of Hazardous Materials, 163: 396-402.

Gupta, V.K., Ali, I. 2008. Removal of endosulfan and methoxychlor from water on carbon slurry. Environmental Science Technology, 42: 766-770.

Gupta, V.K., Rastogi, A. 2008a. Biosorption of lead from aqueous solutions by green algae Spirogyra species: Kinetics and equilibrium. Journal of Hazardous Materials, 152: 407-414.

Gupta, V.K., Rastogi, A. 2008b. Equilibrium and kinetic modeling of cadmium (II) biosorption by nonliving algal biomass Oedogonium sp. from aqueous phase. Journal of Hazardous Materials, 153: 759-766. 
Gupta, V.K., Rastogi, A. 2008c. Biosorption of lead(II) from aqueous solutions by non-living algal biomass Oedogonium sp. and Nostoc sp.-A comparative study. Colloids and Surfaces B: Biointerfaces, 64: 170-178.

Gupta, V.K., Ali, I., Saini, V.K. 2007. Adsorption studies on the removal of Vertigo Blue 49 and Orange DNA13 from aqueous solutions using carbon slurry developed from a waste material. Journal of Colloid and Interface Science, 315: 87-93.

Gupta, V.K., Ali, I., Suhas Saini, V.K. 2006a. Adsorption of 2,4-D and carbofuran pesticides using fertilizer and steel industry wastes. Journal of Colloid and Interface Science, 299: 556-563.

Gupta, V.K., Mittal, A., Gajbe, V., Mittal, J. 2006b. Removal and recovery of the hazardous azo dye acid orange 7 through adsorption over waste materials: Bottom ash and de-oiled Soya. Industrial \& Engineering Chemistry Research, 45:1446-1453.

Gupta, V.K., Sharma, S. 2003. Removal of zinc from aqueous solutions using bagasse fly ash - A low cost adsorbent. Industrial and Engineering Chemistry Research, 42: 6619-6624.

Gupta, V.K., Ali, I. 2001. Removal of DDD and DDE from wastewater using bagasse fly ash, a sugar industry waste. Water Research, 35: 33-40.

Gupta, V.K., Mohan, D., Sharma, S. 1998. Removal of lead from wastewater using bagasse fly ash-a sugar industry waste material. Separation Science and Technology, 33: 1331-1343.

Martinez, N.S.S., Fernandez, J.F., Segura, X.F., Ferrer, A.S. 2003. Preoxidation of an extremely polluted industrial wastewater by the Fenton's reagent. Journal of Hazardous Materials, B101: 315-322.

Moodley, K., Singh, R., Musapatika, E.T., Onyango, M.S., Ochieng, A. 2011. Removal of nickel from wastewater using an agricultural adsorbent. Water SA; (Online http://www.wrc.org.za) 37: 41-64.

Nomanbhay, S.M., Palanisamy, K. 2005. Removal of heavy metal from industrial wastewater using chitosan coated oil palm shell charcoal. Electronic Journal of Biotechnology, 8: 43-53.

Okieimen, F.E., Ogbeifun, D.E., Navala, G.N., Kumash, C.A. 1985. Binding of copper, cadmium and lead by modified cellulosic materials. Bulletin of Environmental Contamination and Toxicology, 34: 860-870.

Peres, J.A., Beltran de Heredia, J., Dominguez, J.R. 2004. Integrated Fenton's reagent - coagulation/ flocculation process for the treatment of cork processing wastewaters. Journal of Hazardous Materials, 107: 115-121.

Sarkar, K.T. 1981. Theory and Practice of Leather Manufacturing. 465 pp., $3^{\text {rd }}$ edition, Ajoy Sorcar 4, Second Avenue, Mahatma Gandhi Road, Madras (Chennai) 600 041, India.

Tam, M., Antal, M. 1999. Preparation of activated carbons from macadamia nut shell and coconut shell by air activation. Industrial Engineering Chemistry Research, 38: 4268-4276.

Toles, C.A., Marshall, W.E., Johns, M.M. 1998. Phosphoric acid activation of nutshells for metals and organic remediation: process optimization. Journal of Chemical Technology and Biotechnology, 72: $255-263$. 